\title{
Neuroprotective effects of melittin on hydrogen peroxide-induced apoptotic cell death in neuroblastoma SH-SY5Y cells
}

\author{
Sang Mi Han ${ }^{1 *+}$, Jung Min Kim" ${ }^{1 \dagger}$, Kwan Kyu Park ${ }^{2}$, Young Chae Chang ${ }^{2}$ and Sok Cheon Pak
}

\begin{abstract}
Background: Free radicals are involved in neuronal cell death in human neurodegenerative diseases. Since ancient times, honeybee venom has been used in a complementary medicine to treat various diseases and neurologic disorders. Melittin, the main component of honeybee venom, has various biologic effects, including anti-bacterial, anti-viral, and anti-inflammatory activities.
\end{abstract}

Methods: We investigated the neuroprotective effects of melittin against $\mathrm{H}_{2} \mathrm{O}_{2}$-induced apoptosis in the human neuroblastoma cell line SH-SY5Y. The neuroprotective effects of melittin on $\mathrm{H}_{2} \mathrm{O}_{2}$-induced apoptosis were investigated using a 3-(4,5-dimethylthiazol-2-yl)-2,5-diphenylterazolium bromide assay, caspase 3 activity, 4,6-diamidino-2-phenylindole staining, a lactate dehydrogenase release assay, Western blots, and reverse transcription-polymerase chain reaction.

Results: The $\mathrm{H}_{2} \mathrm{O}_{2}$-treated cells had decreased cell viability with apoptotic features and increased production of caspase-3. On the other hand, melittin treatment increased cell viability and decreased apoptotic DNA fragmentation. Melittin attenuated the $\mathrm{H}_{2} \mathrm{O}_{2}$-induced decrease in mRNA and protein production of the anti-apoptotic factor $\mathrm{BCl}$-2. In addition, melittin inhibited both the $\mathrm{H}_{2} \mathrm{O}_{2}$-induced mRNA and protein expression of Bax-associated pro-apoptotic factor and caspase-3.

Conclusions: These findings suggest that melittin has potential therapeutic effects as an agent for the prevention of neurodegenerative diseases.

\section{Background}

Oxidative stress is implicated as a causative factor in neurodegenerative diseases, including Alzheimer's disease, Parkinson's disease, Huntington's disease, and amyotrophic lateral sclerosis [1-3]. Reactive oxygen species (ROS), such as superoxide anions, hydroxyl radicals, and hydrogen peroxide $\left(\mathrm{H}_{2} \mathrm{O}_{2}\right)$, are easily generated in redox processes that occur in the human body. These ROS induce oxidative stress, which can cause dysfunction of mitochondria, proteins, DNA and lipid membranes, and eventually disrupt cellular function and integrity [4-7]. Among the various ROS, $\mathrm{H}_{2} \mathrm{O}_{2}$ induces apoptosis in a variety of cells and acts as a precursor of ROS [8]. In addition, $\mathrm{H}_{2} \mathrm{O}_{2}$ diffuses easily in and out of cells and tissues [9]. $\mathrm{H}_{2} \mathrm{O}_{2}$-induced apoptosis

\footnotetext{
* Correspondence: sangmih@korea.kr

${ }^{\dagger}$ Equal contributors

'Department of Agricultural Biology, National Academy of Agricultural Science, RDA, Suwon 441-100, Korea

Full list of author information is available at the end of the article
}

is regulated by the activation of $\mathrm{Bcl}-2$ family members [10]. Upregulation of the pro-apoptotic enzyme Bax and the downregulation of the anti-apoptotic enzyme Bcl-2 both induce cell apoptosis, which could interfere with the execution phases of apoptosis, including the caspase pathway $[11,12]$.

Melittin, the major bioactive component of honeybee venom (Apis mellifera), is a cationic, hemolytic peptide comprising a small linear peptide composed of 26 amino acid residues. The amino-terminal region is hydrophobic, and the carboxyl-terminal region is hydrophilic [13,14]. Previous studies demonstrated that melittin has antibacterial [14], anti-arthritic [15], and anti-inflammatory [16] effects in various cell lines. Melittin also has antiapoptotic effects by activating $\mathrm{Bcl}-2$ and suppressing Bax and caspase 3 in transforming growth factor (TGF)- $\beta 1$ induced injury to hepatocytes [17]. In addition, melittin inhibits caspase and Bax expression in D-galactosamine/ lipopolysaccharide induced acute hepatic failure [18]. The 
mechanisms of the neuroprotective effects of melittin in $\mathrm{H}_{2} \mathrm{O}_{2}$-induced neuroblastoma SH-SY5Y cells, however, have not been fully elucidated.

In the present study, we investigated whether melittin protects against $\mathrm{H}_{2} \mathrm{O}_{2}$-induced neurotoxicity and explored the possible mechanisms of action by examining the upregulation of the anti-apoptotic enzyme $\mathrm{Bcl}-2$ and the downregulation of the pro-apoptotic enzymes Bax and caspase 3 .

\section{Methods}

\section{Materials}

Dulbecco's modified Eagle's medium, fetal bovine serum, and penicillin/streptomycin $(100 \mathrm{IU} / 50 \mu \mathrm{g} / \mathrm{ml})$ were obtained from Invitrogen (Grand Island, NY). Mellitin, $\mathrm{H}_{2} \mathrm{O}_{2}$, 3-(4,5-dimethylthizaol-2-yl)-2,5-diphenyltetrazolium bromide (MTT), dimethyl sulfoxide, 4', 6-diamidino-2-phenylindole (DAPI), 2',7'-dichlorofluorescein diacetate, rabbit anti-Bax, rabbit anti-Bcl-2, and rabbit anti-caspase-3 were purchased from Abcam (Cambridge, MA). Anti-rabbit horseradish peroxidase-linked IgG antibodies were purchased from GE Healthcare Life Science (Buckinghamshire, England, UK). All other chemicals were of analytical grade.

\section{Cell culture and treatment}

Human neuroblastoma SH-SY5Y cells, obtained from the Korea Cell Line Bank (Seoul, Korea), were cultured in Dulbecco's modified Eagle's medium supplemented with $10 \%(\mathrm{v} / \mathrm{v})$ fetal bovine serum, and $1 \%$ penicillin/ streptomycin at $37^{\circ} \mathrm{C}$ under $5 \% \mathrm{CO}_{2}$ in air. To determine the effect of melittin on $\mathrm{H}_{2} \mathrm{O}_{2}$-exposed SH-SY5Y cells, SH-SY5Y cells were treated with various doses of melittin for $1 \mathrm{~h}$ before $\mathrm{H}_{2} \mathrm{O}_{2}$ exposure for $6 \mathrm{~h} . \mathrm{H}_{2} \mathrm{O}_{2}$ was prepared immediately before use as a $20 \mathrm{mM}$ stock. Melittin was dissolved in phosphate-buffered saline (PBS) and the stock solutions were added directly to the culture media. In a single experiment, each treatment was performed in triplicate.

\section{Cell viability assay}

Cell viability was determined by MTT assay. SH-SY5Y cells were seeded in 96-well plates at density of $8 \times 10^{4}$ cells/well and incubated for $48 \mathrm{~h}$ prior to experimental treatments. The cells were pre-incubated with or without melittin following incubation with $\mathrm{H}_{2} \mathrm{O}_{2}$ for $24 \mathrm{~h}$. The cultured medium was removed and $50 \mu \mathrm{l}$ MTT solution $(1 \mathrm{mg} / \mathrm{ml}$ in PBS) was placed in each well. After incubation at $37^{\circ} \mathrm{C}$ for $4 \mathrm{~h}$, the solution was carefully removed, and $150 \mu \mathrm{l}$ dimethyl sulfoxide was added. Absorbance was measured at $570 \mathrm{~nm}$ using a microplate reader (Bio-Tek Instruments, Inc., Winooski, VT).

\section{Lactate dehydrogenase release assay}

Lactate dehydrogenase (LDH) is released into the cell culture supernatant when cells undergo by apoptosis or necrosis. LDH levels were measured using a Cytotoxicity Cell Death kit (Takara Bio, Shiga, Japan) according to the manufacturer's instructions. Briefly, the cells $\left(8 \times 10^{4}\right.$ cells/well) were seeded in 96-well plates and then incubated with $100 \mu \mathrm{M} \mathrm{H}_{2} \mathrm{O}_{2}$ for $24 \mathrm{~h}$ with or without melittin pretreatment for $1 \mathrm{~h}$. For analysis, $100 \mu \mathrm{l}$ supernatant was transferred to a new 96 well plate, and $100 \mu \mathrm{l}$ of reaction mixture was added to each well and incubated at $37^{\circ} \mathrm{C}$ for $30 \mathrm{~min}$. Absorbance was measured at $490 \mathrm{~nm}$ using microplate reader (Bio-Tek Instruments, Inc.). $\mathrm{LDH}$ release was determined in cells treated with $2 \%$ Triton X-100 (high control); the assay medium served as the low control and was subtracted from all absorbance measurements.

\section{Nuclear staining with DAPI}

Nuclear morphology was assessed by staining with DAPI. Cells $\left(1 \times 10^{5}\right.$ cells/well $)$ were seeded on coverslips in 6-well plates for $48 \mathrm{~h}$ and then treated with $100 \mu \mathrm{M}$ of $\mathrm{H}_{2} \mathrm{O}_{2}$ for $24 \mathrm{~h}$ with or without melittin pretreatment for $1 \mathrm{~h}$. The cells were washed twice with PBS and fixed with $1 \%$ paraformaldehyde for $15 \mathrm{~min}$. The fixed cells were washed twice with PBS and stained with 4', 6-DAPI $(1 \mu \mathrm{g} / \mathrm{ml})$ for $10 \mathrm{~min}$ at $37^{\circ} \mathrm{C}$ in the dark. Cells were washed twice with PBS and were observed using a fluorescent microscope.

\section{Caspase-3 activity}

Activation of caspase- 3 was determined according to the protocols recommended for the caspase-3 assay kit (R\&D Systems, Minneapolis, MN). In brief, the cells were lysed and centrifuged to obtain the supernatant. The supernatant was added to the reaction mixture containing dithiothreitol and caspase- 3 substrate, and incubated for $2 \mathrm{~h}$ at $37^{\circ} \mathrm{C}$. Absorbance was measured at a wavelength of $405 \mathrm{~nm}$ using a microplate reader (BioTek Instruments, Inc.).

\section{Western blot analysis}

Cell were lysed with ice-cold lysis buffer containing protease inhibitors and centrifuged at $14,000 \mathrm{rpm}$ for $10 \mathrm{~min}$. The protein content of each supernatant was determined using a Bradford assay with bovine serum albumin as the protein standard. Samples $(10 \mu \mathrm{g})$ were separated by polyacrylamide gel (10\%) electrophoresis, and then transferred to a polyvinylidene difluoride membrane $(0.45 \mu \mathrm{m}$, Immobilon-P Transfer membrane, Millipore, Billerica, MA). The membranes were blocked with $5 \%$ non-fat dry milk in Tris-buffered saline containing $0.1 \%$ Tween 20 (TBST) for $1 \mathrm{~h}$. After blocking, membranes were incubated with Bcl-2, Bax, and caspase-3 antibody (Abcam) in TBST overnight at $4^{\circ} \mathrm{C}$. After washing in TBST, the membranes were incubated with horseradish peroxidase-conjugated secondary antibodies (GE 
Healthcare Life Science) at a 1:5000 dilution for $1 \mathrm{~h}$ at room temperature. After washing with TBST, proteins were visualized using a Super Signal West Pico Kit (Pierce, Rockford, IL) detection system. Densitometric analysis was performed using Quantity One (Bio-Rad, Hercules, CA) to scan the signals.

\section{RNA extraction and reverse transcription-polymerase chain reaction}

Total RNA was isolated using the Total RNA Purification kit (Nanohelix, Daejeon, Korea) according to the manufacturer's instructions. Reverse transcription of total RNA $(1 \mu \mathrm{g})$ was performed for $1 \mathrm{~h}$ at $45^{\circ} \mathrm{C}$ using RT Premix kit (Oligo dT primer; iNtRON Biotechnology, Sungnam, Korea). The reaction was terminated by heating at $95^{\circ} \mathrm{C}$ at $5 \mathrm{~min}$. cDNA was amplified by polymerase chain reaction (PCR) Premix kit (i-Taq) (iNtRON Biotechnology). Sequences of primers for Bcl-2 cDAN are: forward primer 5'-CGACTTCGCCGAGATGTCCAGCCAG-3' and reverse primer 5'-ACTTGTGGCCCAGATAGGCACCCA G-3', for Bax cDNA are: forward primer 5'-ACCAAG AAGCTGAGCGAGTGTC-3' and reverse primer $5^{\prime}$-TG TCCAGCCCATGATGGTTC-3', and for glyceraldehyde3-phosphate dehydrogenase (GAPDH) cDNA are: forward primer 5'-AATGACCCCTTCATTGAC-3' and reverse primer 5'-TCCACGACGTACTCAGCGC-3'. PCR for Bcl-2 and GAPDH) [19] was performed with 35 cycles as follows: denaturation at $94^{\circ} \mathrm{C}$ for $30 \mathrm{~s}$, annealing at $61^{\circ} \mathrm{C}$ for $1 \mathrm{~min}$, and extension at $72^{\circ} \mathrm{C}$ for $1 \mathrm{~min}$. PCR for Bax [20] was performed with 40 cycles and the reaction conditions were: denaturation at $94^{\circ} \mathrm{C}$ for $45 \mathrm{~s}$, annealing at $61^{\circ} \mathrm{C}$ for $1 \mathrm{~min}$, and extension at $72^{\circ} \mathrm{C}$ for 1 min using PCR Thermal Cycler Dice (Takara, Shiga, Japan). The PCR products were analyzed by $2 \%$ agarose gel electrophoresis with ethidium bromide. The signal intensity of each band was quantified and normalized against GAPDH. Densitometric analysis was carried out using Quantity One (Bio-Rad) to scan the signals.

\section{Statistical analysis}

All data are expressed as the mean \pm standard error of the mean (SEM). Statistical differences among groups were calculated by analysis of variance (ANOVA) followed by Duncan's multiple range test (SPSS version 18.0, Chicago, IL). Differences with a $\mathrm{p}$ value less than 0.05 were considered significant.

\section{Results}

Melittin inhibited $\mathrm{H}_{2} \mathrm{O}_{2}$-induced apoptosis of SH-SY5Y cells We examined the protective effects of melittin against $\mathrm{H}_{2} \mathrm{O}_{2}$-induced apoptotic cell death of SH-SY5Y. SHSY5Y cells were exposed to $100-400 \mu \mathrm{M} \mathrm{H}_{2} \mathrm{O}_{2}$ for $6 \mathrm{~h}$. The lowest dose of $\mathrm{H}_{2} \mathrm{O}_{2}(100 \mu \mathrm{M})$ induced $66.0 \%$ cell viability compared with the control (data not shown) and was therefore used for the following experiments. SH-SY5Y cells were pretreated with various doses of melittin for $1 \mathrm{~h}$, followed by $100 \mu \mathrm{M} \mathrm{H}_{2} \mathrm{O}_{2}$ for $6 \mathrm{~h}$. In Figure $1 \mathrm{~A}$, the low doses of melittin $(0.5$ and $1 \mu \mathrm{g} / \mathrm{ml})$ significantly attenuated the $\mathrm{H}_{2} \mathrm{O}_{2}$-induced cytotoxicity.

To further investigate the protective effect of melittin, we measured $\mathrm{LDH}$ release (Figure $1 \mathrm{~B}$ ). $\mathrm{LDH}$ release significantly increased after exposure with $100 \mu \mathrm{M} \mathrm{H_{2 } \mathrm { O } _ { 2 }}$ for $6 \mathrm{~h}$. In contrast, the LDH release was decreased by pretreatment with 0.5 and $1 \mu \mathrm{g} / \mathrm{ml}$ melittin for $1 \mathrm{~h}$ compared to the $\mathrm{H}_{2} \mathrm{O}_{2}$ only treated group. In Figure $1 \mathrm{~B}$, the $2 \mu \mathrm{g} / \mathrm{ml}$ dose is also labeled as significantly different from the $\mathrm{H}_{2} \mathrm{O}_{2}$ group, although the data do not look significantly different. The higher dose of melittin $(2 \mu \mathrm{g} / \mathrm{ml})$, however, significantly increased LDH release. Therefore, only the 0.5 to $1 \mu \mathrm{g} / \mathrm{ml}$ doses of melittin were used for subsequent experiments.

\section{Melittin protected $\mathrm{H}_{2} \mathrm{O}_{2}$-induced morphological changes of SH-SY5Y cells}

The protective effects of melittin were confirmed by morphological observations (Figure 2A). Morphologic

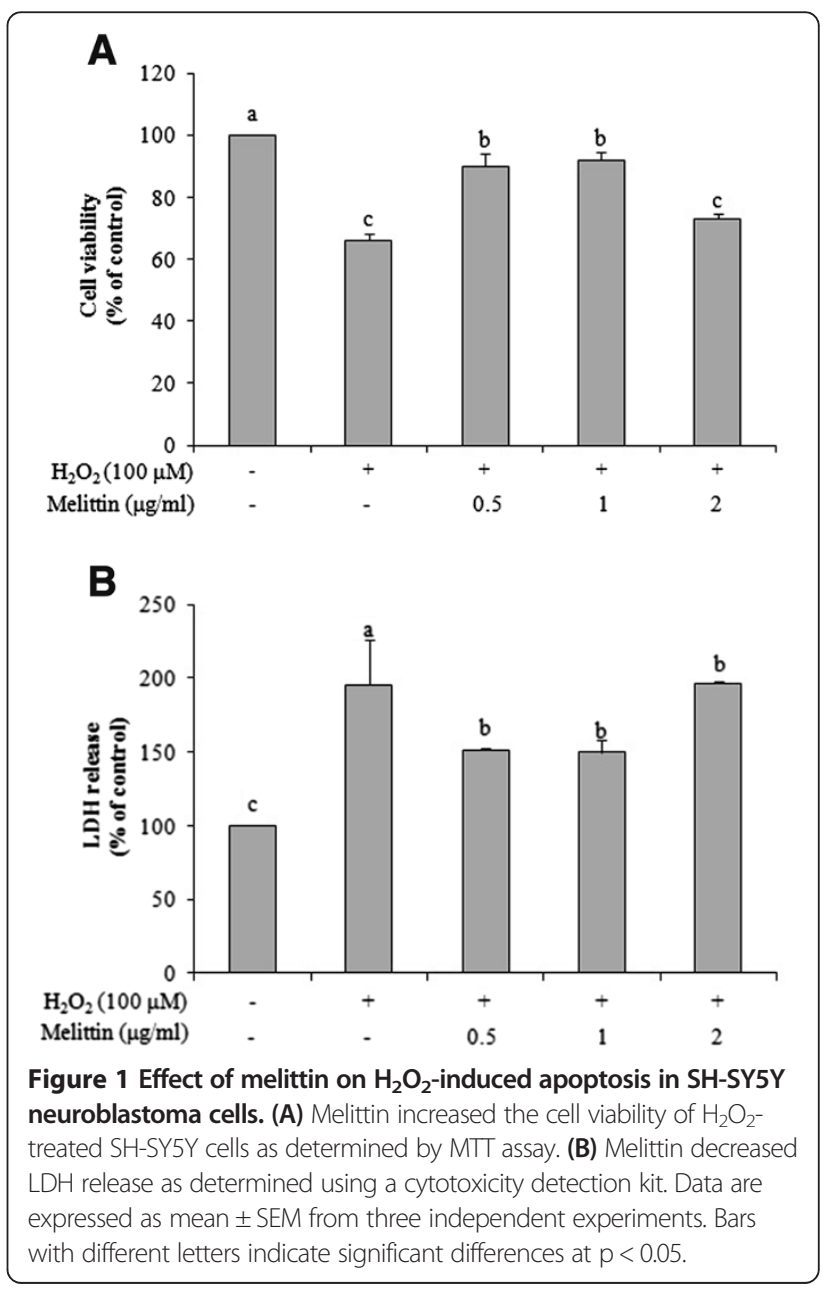




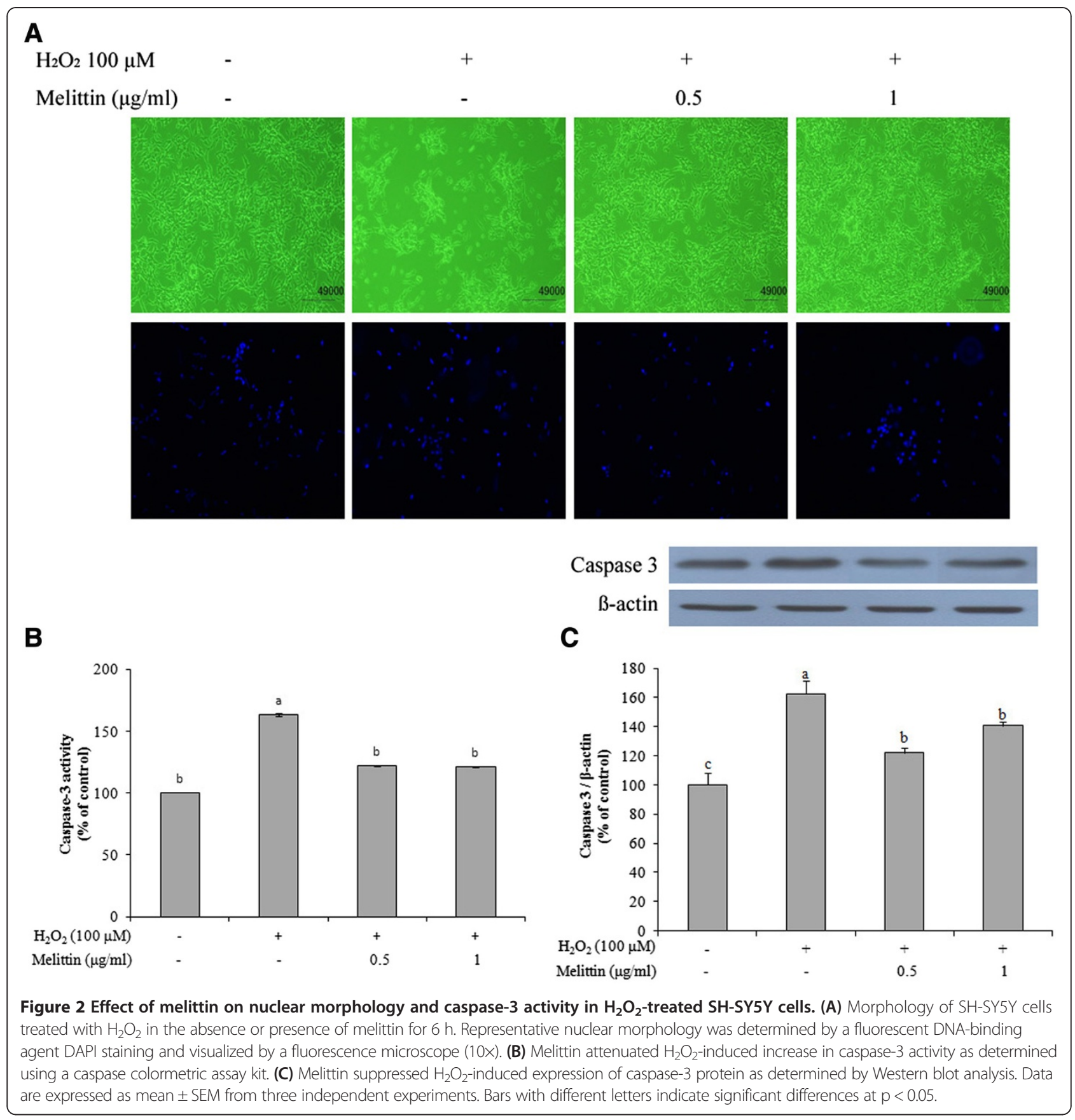

changes were observed in $100 \mu \mathrm{M} \mathrm{H}_{2} \mathrm{O}_{2}$-treated $\mathrm{SH}$ SY5Y cells. Pretreatment with melittin prevented the $\mathrm{H}_{2} \mathrm{O}_{2}$-induced morphologic changes. DAPI staining also showed nuclear condensation and DNA fragmentation following treatment with $100 \mu \mathrm{M} \mathrm{H}_{2} \mathrm{O}_{2}$. Pretreatment with melittin inhibited these apoptotic features.

\section{Melittin suppressed caspase-3 activation and expression} of $\mathrm{H}_{2} \mathrm{O}_{2}$-treated SH-SY5Y cells

We investigated the protective effect of melittin on caspase-signaling. In $\mathrm{H}_{2} \mathrm{O}_{2}$-treated $\mathrm{SH}-\mathrm{SY} 5 \mathrm{Y}$ cells, caspase-
3 activity was significantly increased by $63 \%$ of the control, but pretreatment with 0.5 and $1 \mu \mathrm{g} / \mathrm{ml}$ melittin attenuated the $\mathrm{H}_{2} \mathrm{O}_{2}$-induced increase in caspase- 3 activity by approximately $41 \%$ and $42 \%$, respectively (Figure $2 \mathrm{~B}$ ). In addition, we examined caspase-3 protein expression in $\mathrm{H}_{2} \mathrm{O}_{2}$ and/or melittin-treated SH-SY5Y cells by Western blotting. $\mathrm{H}_{2} \mathrm{O}_{2}$ treatment increased caspase- 3 protein expression by $63 \%$ compared to that of control (Figure 2C). Pretreatment with melittin, however, suppressed the $\mathrm{H}_{2} \mathrm{O}_{2}$ induced expression of caspase 3 protein $(0.5 \mu \mathrm{g} / \mathrm{ml}: 22 \%$; $1 \mu \mathrm{g} / \mathrm{ml}: 41 \%)$ to level similar to the control. 


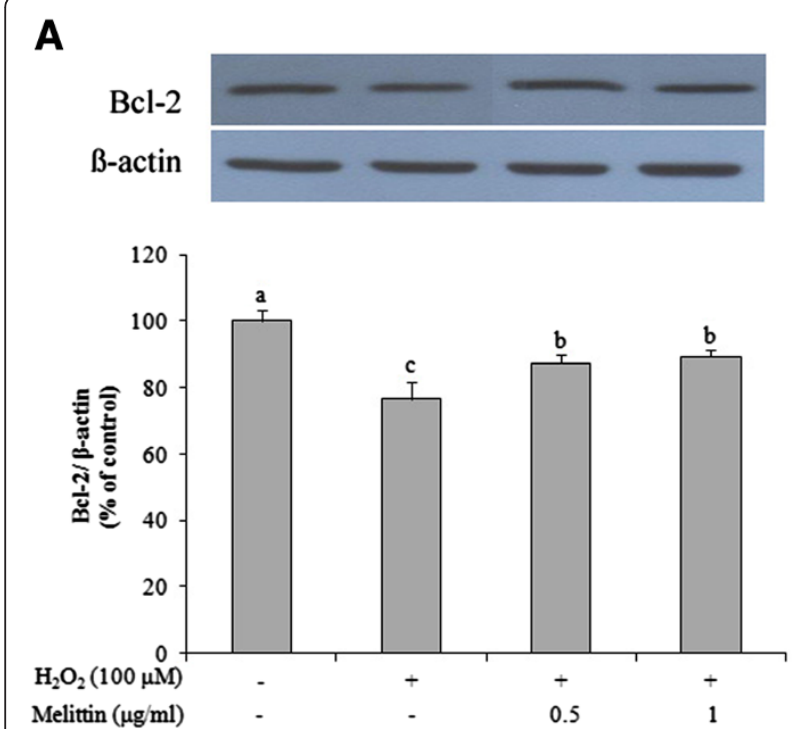

B
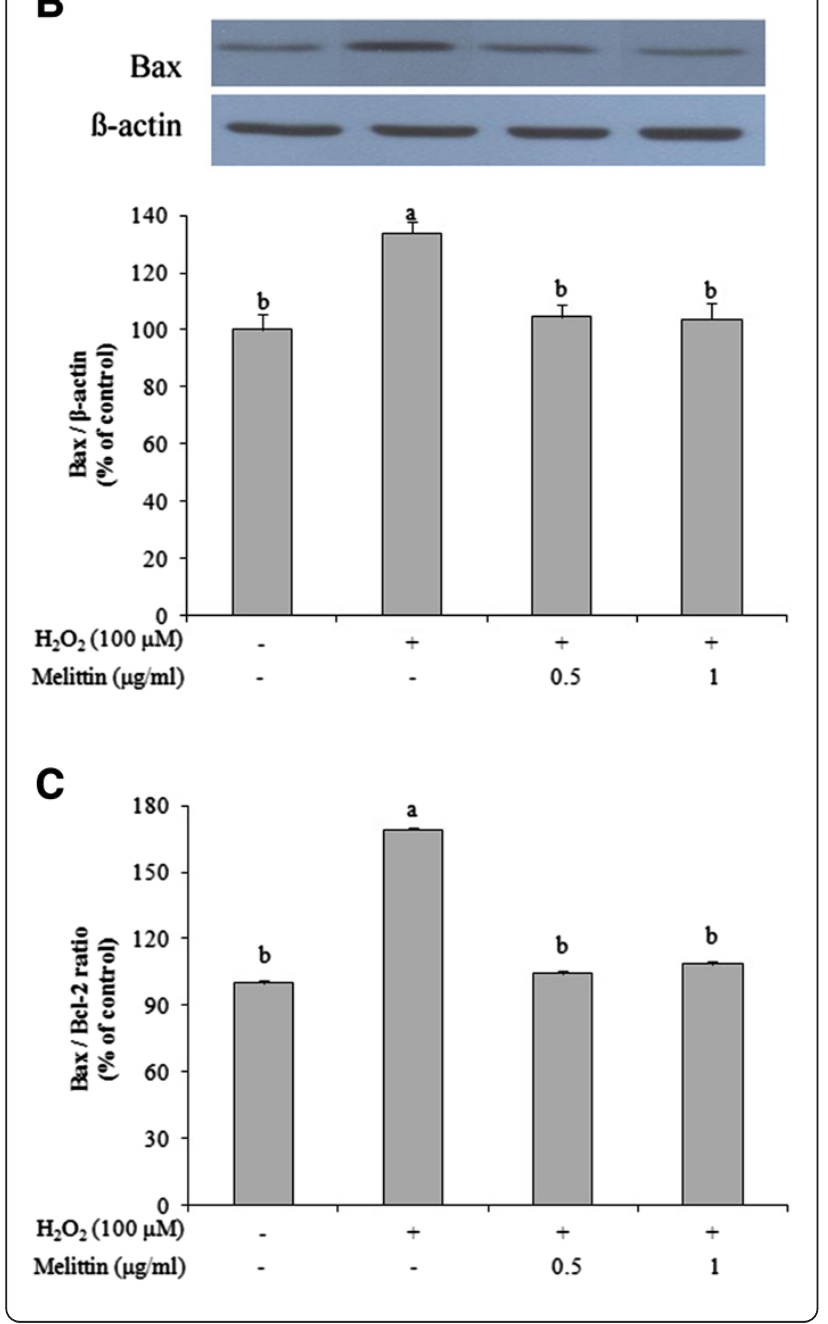

Figure 3 Effect of melittin on protein expression of $\mathrm{Bcl}-2$ and Bax in $\mathrm{H}_{2} \mathrm{O}_{2}$-treated SH-SY5Y cells. (A) Melittin inhibited the decrease of $\mathrm{BCl}-2$ protein as measured by Western blot analysis. (B) Melittin blocked the increase of Bax protein as determined by Western blot analysis. (C) Melittin caused a low Bax/BCl-2 protein ratio. Data are expressed as mean \pm SEM from 3 independent experiments. Bars with different letters indicate significant differences at $p<0.05$.

\section{Melittin decreased the ratio of $\mathrm{Bax} / \mathrm{Bcl}-2$ of $\mathrm{H}_{2} \mathrm{O}_{2}$-treated SH-SY5Y cells}

The anti-apoptotic enzyme, Bcl-2 and the pro-apoptotic enzyme, Bax play important roles in regulating cell death and cell survival $[11,12]$. Therefore, we used Western blotting to investigate whether the expression of $\mathrm{Bcl}-2$ and Bax protein was affected by $\mathrm{H}_{2} \mathrm{O}_{2}$ and/or melittin (Figure 3). In $\mathrm{H}_{2} \mathrm{O}_{2}$-treated $\mathrm{SH}-\mathrm{SY} 5 \mathrm{Y}$ cells, the expression of $\mathrm{Bcl}-2$ protein was significantly decreased whereas the expression of Bax protein was significantly increased, as compared with the control, which resulted in a high $\mathrm{Bax} / \mathrm{Bcl}-2$ ratio. Pretreatment with 0.5 and $1 \mu \mathrm{g} / \mathrm{ml}$ melittin, however, inhibited the decrease in $\mathrm{Bcl}-2$ protein and blocked the increase in Bax protein to levels similar to those of the control. In addition, melittin pretreatment led to a significantly lower $\mathrm{Bax} / \mathrm{Bcl}-2$ ratio. Next, we measured the expression of $\mathrm{Bcl}-2$ and Bax mRNA using reverse transcription-PCR. Changes in the expression of Bcl-2 and Bax protein induced by $\mathrm{H}_{2} \mathrm{O}_{2}$ and/or melittin were due to changes in the mRNA expression (Figure 4). These findings indicate the potential of melittin to inhibit $\mathrm{H}_{2} \mathrm{O}_{2}$-induced SH-SY5Y apoptotic cell death.

\section{Discussion}

Oxidative stress induces neuronal cell death, which is implicated in many neurodegenerative disorders, such as Alzheimer's disease, Parkinson's disease, Huntington's disease and amyotrophic lateral sclerosis [1-3]. The underlying mechanism, however, is poorly understood. Therefore, in the present study we investigated the possible mechanism by which melittin exerts its protective effects in $\mathrm{H}_{2} \mathrm{O}_{2}$-induced SH-SY5Y apoptotic cell death.

Several studies have demonstrated that $\mathrm{H}_{2} \mathrm{O}_{2}$-induced apoptotic cell death depends on the concentration and exposure time of $\mathrm{H}_{2} \mathrm{O}_{2}$ [21]. Gardner et al. demonstrated that moderate concentrations of $\mathrm{H}_{2} \mathrm{O}_{2}$ induced DNA cleavage and morphologic changes leading to apoptosis [4]. In the present study, we confirmed that SH-SY5Y cells treated with 0 to $400 \mu \mathrm{M} \mathrm{H}_{2} \mathrm{O}_{2}$ exhibited a dosedependent loss of cell viability (data not shown). Pretreatment with 0.5 to $1 \mu \mathrm{g} / \mathrm{ml}$ melittin, however, significantly protected cell viability, which was confirmed by the lack of morphologic changes in melittin-pretreated cells. These findings suggest that melittin prevented SH-SY5Y cells from undergoing $\mathrm{H}_{2} \mathrm{O}_{2}$-induced apoptotic cell death. 


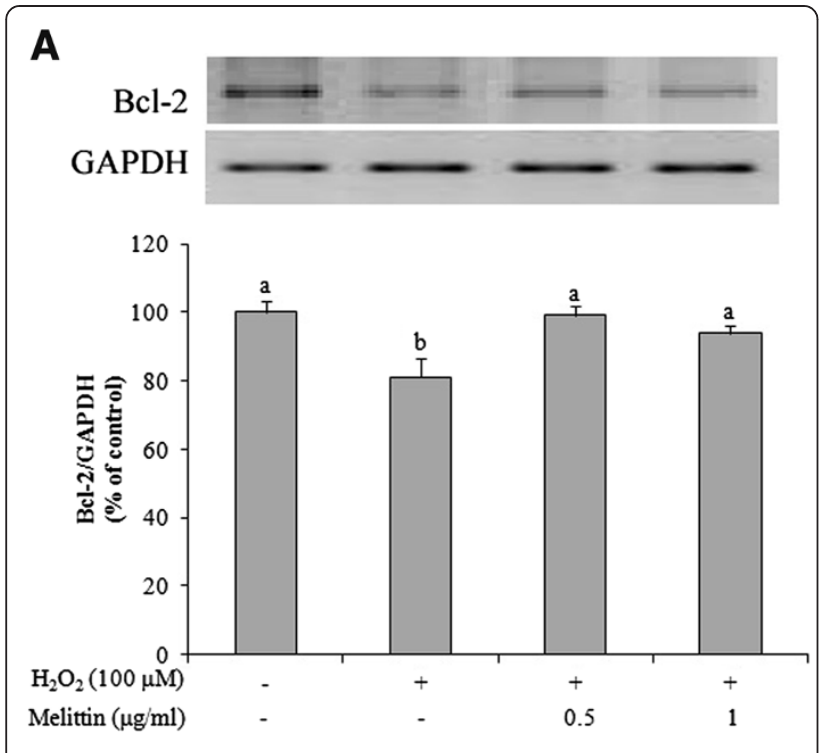

B
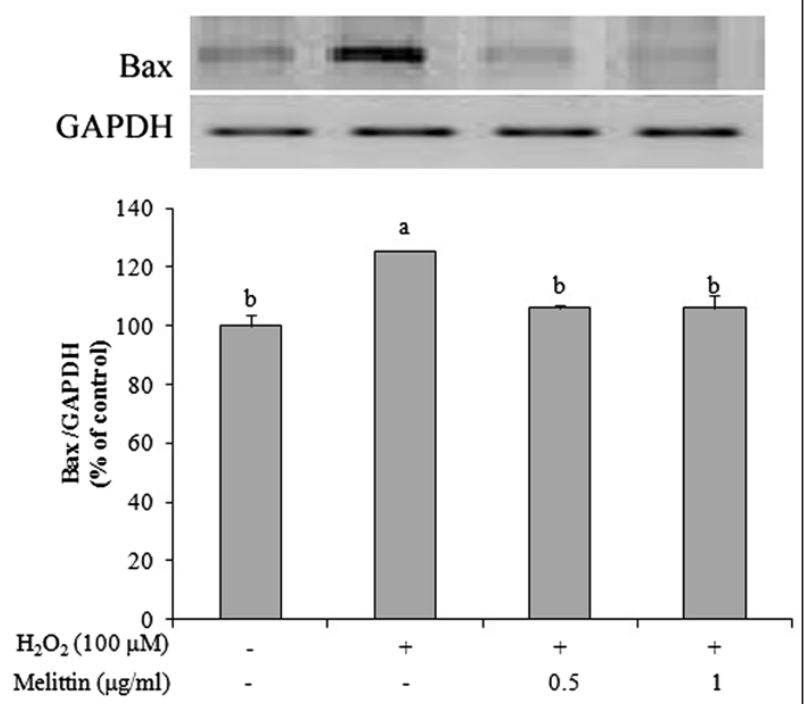

C

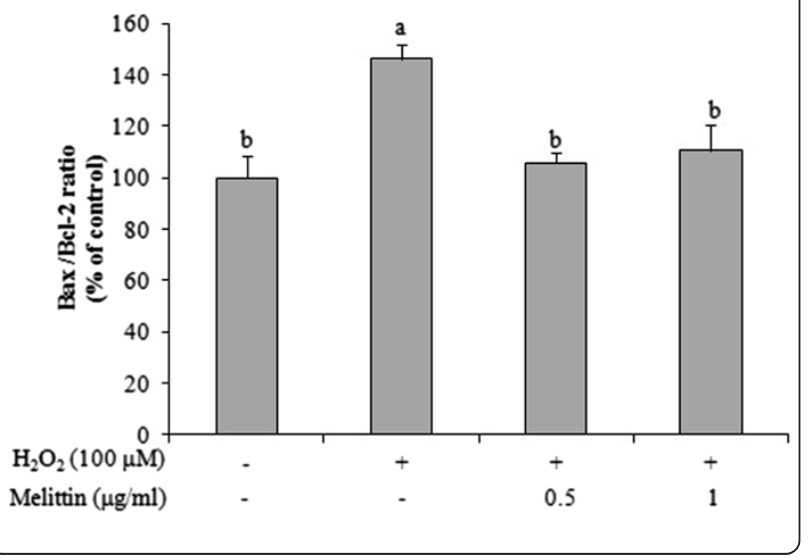

Figure 4 Effect of melittin on mRNA expression of $\mathrm{Bcl}-2$ and Bax in $\mathrm{H}_{2} \mathrm{O}_{2}$-treated SH-SY5Y cells. (A) Melittin inhibited the decrease of $\mathrm{BCl}-2$ mRNA as determined by reverse transcription-PCR. (B) Melittin blocked the increase of Bax mRNA as measured by reverse transcription-PCR. (C) Melittin caused a low Bax/BCl-2 mRNA ratio. Data are expressed as mean \pm SEM from 3 independent experiments. Bars with different letters indicate significant differences at $p<0.05$.

Staining the apoptotic nuclei with DAPI revealed that melittin slightly attenuated the induction of apoptotic features, such as cell shrinkage, nuclear condensation and DNA fragmentation, compared with cells treated with $\mathrm{H}_{2} \mathrm{O}_{2}$ alone.

Apoptotic cell death in SH-SY5Y cells induced by $\mathrm{H}_{2} \mathrm{O}_{2}$ is mediated by mitochondria through intrinsic pathways that activate caspases [22]. The Bcl-2 family contains two groups, an anti-apoptotic group (Bcl-2 and Bcl-x L) and a pro-apoptotic group (Bax, Bid and Bak), and these groups play a crucial role in the mitochondrial-related apoptosis pathway [23,24]. Anti-apoptotic Bcl-2, which inhibited the release of cytochrome $\mathrm{c}$, is located in the outer mitochondrial membrane [25]. In contrast, pro-apoptotic factor, Bax, resides in the cytosol and translocates to the outer mitochondrial membrane, which might lead to the loss of mitochondrial membrane potential, an increase in mitochondrial membrane permeability and the release of cytochrome $\mathrm{c}$ from the intermembrane space into the cytosol, leading to cell death [26]. The $\mathrm{Bcl}-2$ family regulates the apoptotic process through balancing of pro-apoptotic (Bax) and anti-apoptotic (Bcl-2) products [24]. In this regard, the $\mathrm{Bax} / \mathrm{Bcl}-2$ ratio is suggested to be a useful predictor of apoptotic cell death $[24,27]$. In present study, we examined the protein and mRNA expression of $\mathrm{Bcl}-2$ and Bax in $\mathrm{H}_{2} \mathrm{O}_{2}$-induced apoptotic cell death in $\mathrm{SH}-\mathrm{SY} 5 \mathrm{Y}$ cells. Our findings indicate that $\mathrm{H}_{2} \mathrm{O}_{2}$ induced changes in the protein and mRNA expression of Bcl-2 family, Bcl-2, and Bax, in SH-SY5Y cells, but pretreatment with melittin enhanced the protein and mRNA expression of $\mathrm{Bcl}-2$ and reduced the protein and mRNA expression of Bax in $\mathrm{SH}$ SY5Y cells. The Bax/Bcl-2 ratio increased after treatment with only $\mathrm{H}_{2} \mathrm{O}_{2}$, while pretreatment with melittin inhibited the increase in the $\mathrm{Bax} / \mathrm{Bcl}-2$ ratio. These findings suggest that melittin modulates the effect of $\mathrm{H}_{2} \mathrm{O}_{2}$ treatment on the protein and mRNA expression of $\mathrm{Bcl}-2$ and Bax.

Caspase 3 acts as an apoptotic executor by activating DNA fragmentation [28]. In apoptotic processes, cytochrome $\mathrm{c}$ is released from the mitochondria to the cytosol. The released cytochrome $\mathrm{c}$ activates caspase- 9 which in turn triggers the activation of caspase- 3 , which induces cell death [28]. Increased caspase-3 activity is associated with an increase in the Bax/Bcl-2 ratio [26]. Although we did not examine the expression of cytochrome $\mathrm{c}$ and caspase- 9 
in the present study, our findings indicate that $\mathrm{H}_{2} \mathrm{O}_{2}$-induced apoptosis was associated with the expression and activation of caspase-3, which led to an increase in the Bax/ $\mathrm{Bcl}-2$ ratio. Pretreatment with melittin, however, inhibited the expression and activation of caspase-3, suggesting that melittin has potential anti-apoptotic effects by modulating the $\mathrm{H}_{2} \mathrm{O}_{2}$-induced protein and mRNA expression of Bcl-2 and Bax by downregulating caspase- 3 protein expression and activation.

Melittin is a residue of the main toxic compound in honeybee venom, and is a small linear peptide composed of 26 amino acids [13,14]. Although melittin is a toxic peptide, several studies have demonstrated various properties of melittin, including anti-bacterial, anti-arthritic, and anti-inflammatory effects [14-16]. Pratt et al. reported that melittin $(2 \mu \mathrm{M})$ did not disrupt cell membranes of leukocytes [29]. Also, a recent study showed that a lower dose of melittin $(0.5$ and $1 \mu \mathrm{g} / \mathrm{ml})$ protected hepatocytes against TGF- $\beta 1$ [17].

\section{Conclusions}

The findings of the present study indicate that melittin suppressed $\mathrm{H}_{2} \mathrm{O}_{2}$-induced apoptotic cell death in $\mathrm{SH}$ SY5Y neuroblastoma cells by inducing an increase in the anti-apoptotic enzyme, Bcl-2 and a decrease in proapoptotic enzymes, such as Bax and caspase-3. Although further studies are needed, our results demonstrate the potential usefulness of melittin as an agent for the prevention of neurodegenerative diseases.

\section{Competing interests}

The authors declare that they have no competing interests.

\section{Authors' contributions}

SMH designed, carried out the research project and wrote the manuscript. JMK carried out the experiments. KKP and YCC contributed to the interpretation of data. SCP was responsible for the proofreading. All authors read and approved the final manuscript.

\section{Acknowledgements}

This work was supported by a grant from the Next BioGreen21 Program, Rural Development Administration (Code \#: PJ009534), Korea.

\section{Author details}

${ }^{1}$ Department of Agricultural Biology, National Academy of Agricultural Science, RDA, Suwon 441-100, Korea. ${ }^{2}$ College of Medicine, Catholic University of Daegu, Daegu 712-702, Korea. ${ }^{3}$ School of Biomedical Sciences, Charles Sturt University, Bathurst NSW 2795, Australia.

Received: 10 January 2014 Accepted: 22 July 2014

Published: 5 August 2014

\section{References}

1. Alexi T, Borlongan CV, Faull RL, Williams CE, Clark RG, Gluckman PD, Hughes $P E:$ Neuroprotective strategies for basal ganglia degeneration: Parkinson's and Huntington's diseases. Prog Neurobio/ 2000, 60:409-470.

2. Wu DC, Ré DB, Nagai M, Ischiropoulos H, Przedborski S: The inflammatory NADPH oxidase enzyme modulates motor neuron degeneration in amyotrophic lateral sclerosis mice. Proc Natl Acad Sci U S A 2006 103:12132-12137.

3. Zhang $Y$, Dawson VL, Dawson TM: Oxidative stress and genetics in the pathogenesis of Parkinson's disease. Neurobiol Dis 2000, 7:240-250.
4. Gardner AM, Xu FH, Fady C, Jacoby FJ, Duffey DC, Tu Y, Lichtenstein A: Apoptotic vs. nonapoptotic cytotoxicity induced by hydrogen peroxide. Free Radic Biol Med 1997, 22:73-83.

5. Gorman AM, McGowan A, O'Neill C, Cotter T: Oxidative stress and apoptosis in neurodegeneration. J Neurol Sci 1996, 139:45-52.

6. Hall ED, Braughler JM: Central nervous system trauma and stroke. II. Physiological and pharmacological evidence for involvement of oxygen radicals and lipid peroxidation. Free Radic Biol Med 1989, 6:303-313.

7. McCord JM: Oxygen-derived free radicals in postischemic tissue injury. N Engl J Med 1985, 312:159-163.

8. Sherer TB, Betarbet R, Stout AK, Lund S, Baptista M, Panov AV, Cookson MR, Greenamyre JT: An in vitro model of Parkinson's disease: linking mitochondrial impairment to altered alpha-synuclein metabolism and oxidative damage. J Neurosci 2002, 22:7006-7015.

9. Barbouti A, Doulias PT, Nousis L, Tenopoulou M, Galaris D: DNA damage and apoptosis in hydrogen peroxide-exposed Jurkat cells: bolus addition versus continuous generation of $\mathrm{H}(2) \mathrm{O}(2)$. Free Radic Biol Med 2002, 33:691-702.

10. Suematsu N, Hosoda M, Fujimori K: Protective effects of quercetin against hydrogen peroxide-induced apoptosis in human neuronal SH-SY5Y cells. Neurosci Lett 2011, 504:223-227.

11. Galluzzi L, Blomgren K, Kroemer G: Mitochondrial membrane permeabilization in neuronal injury. Nat Rev Neurosci 2009, 10:481-494

12. Kroemer G, Galluzzi L, Brenner C: Mitochondrial membrane permeabilization in cell death. Physiol Rev 2007, 87:99-163.

13. Gevod VS, Birdi KS: Melittin and the $8-26$ fragment. Differences in ionophoric properties as measured by monolayer method. Biophys $\mathrm{J}$ 1984, 45:1079-1083.

14. Han S, Yeo J, Baek H, Lin SM, Meyer S, Molan P: Postantibiotic effect of purified melittin from honeybee (Apis mellifera) venom against Escherichia coli and Staphylococcus aureus. J Asian Nat Prod Res 2009, 11:796-804.

15. Park HJ, Lee SH, Son DJ, Oh KW, Kim KH, Song HS, Kim GJ, Oh GT, Yoon DY, Hong JT: Antiarthritic effect of bee venom: inhibition of inflammation mediator generation by suppression of NF-kappaB through interaction with the p50 subunit. Arthritis Rheum 2004, 50:3504-3515.

16. Park HJ, Son DJ, Lee CW, Choi MS, Lee US, Song HS, Lee JM, Hong JT: Melittin inhibits inflammatory target gene expression and mediator generation via interaction with IkappaB kinase. Biochem Pharmacol 2007 73:237-247.

17. Lee WR, Park JH, Kim KH, Park YY, Han SM, Park KK: Protective effects of melittin on transforming growth factor- $\beta 1$ injury to hepatocytes via anti-apoptotic mechanism. Toxicol Appl Pharmacol 2011, 256:209-215.

18. Park JH, Kim KH, Lee WR, Han SM, Park KK: Protective effect of melittin on inflammation and apoptosis in acute liver failure. Apoptosis 2012, 17:61-69.

19. Zhang L, Yu H, Sun Y, Lin X, Chen B, Tan C, Cao G, Wang Z: Protective effects of salidroside on hydrogen peroxide-induced apoptosis in SH-SY5Y human neuroblastoma cells. Eur J Pharmacol 2007, 564:18-25.

20. Liu JJ, Huang RW, Lin DJ, Peng J, Wu XY, Lin Q, Pan XL, Song YQ, Zhang $\mathrm{MH}, \mathrm{Hou} \mathrm{M}$, Chen F: Expression of survivin and bax/bcl-2 in peroxisome proliferator activated receptor-gamma ligands induces apoptosis on human myeloid leukemia cells in vitro. Ann Oncol 2005, 16:455-459.

21. Chen L, Liu L, Yin J, Luo Y, Huang S: Hydrogen peroxide-induced neuronal apoptosis is associated with inhibition of protein phosphatase $2 \mathrm{~A}$ and 5 , leading to activation of MAPK pathway. Int J Biochem Cell Biol 2009, 41:1284-1295

22. Budihardjo I, Oliver H, Lutter M, Luo X, Wang X: Biochemical pathways of caspase activation during apoptosis. Annu Rev Cell Dev Biol 1999, 15:269-290

23. Fei $Q$, Ethell DW: Maneb potentiates paraquat neurotoxicity by inducing key Bcl-2 family members. J Neurochem 2008, 105:2091-2097.

24. Youle RJ, Strasser A: The BCL-2 protein family: opposing activities that mediate cell death. Nat Rev Mol Cell Biol 2008, 9:47-59.

25. Borner $\mathrm{C}$ : The $\mathrm{BCl}-2$ protein family: sensors and checkpoints for life-ordeath decisions. Mol Immunol 2003, 39:615-647.

26. Chinnaiyan AM, Orth K, O'Rourke K, Duan H, Poirier GG, Dixit VM: Molecular ordering of the cell death pathway. $\mathrm{Bcl}-2$ and $\mathrm{BCl}-\mathrm{xL}$ function upstream of the CED-3-like apoptotic proteases. J Biol Chem 1996, 271:4573-4576. 
27. Cregan SP, MacLaurin JG, Craig CG, Robertson GS, Nicholson DW, Park DS, Slack RS: Bax-dependent caspase-3 activation is a key determinant in p53-induced apoptosis in neurons. J Neurosci 1999, 18:7860-7869.

28. Grütter MG: Caspases: key players in programmed cell death. Curr Opin Struct Biol 2000, 10:649-655.

29. Pratt JP, Ravnic DJ, Huss HT, Jiang X, Orozco BS, Mentzer SJ: Melittininduced membrane permeability: a nonosmotic mechanism of cell death. In Vitro Cell Dev Biol Anim 2005, 41:349-355.

doi:10.1186/1472-6882-14-286

Cite this article as: Han et al:: Neuroprotective effects of melittin on

hydrogen peroxide-induced apoptotic cell death in neuroblastoma $\mathrm{SH}$ -

SY5Y cells. BMC Complementary and Alternative Medicine 2014 14:286.

\section{Submit your next manuscript to BioMed Central and take full advantage of:}

- Convenient online submission

- Thorough peer review

- No space constraints or color figure charges

- Immediate publication on acceptance

- Inclusion in PubMed, CAS, Scopus and Google Scholar

- Research which is freely available for redistribution 